Fig. 3. The branched chambers of Cliona celata exposed by the removal of the surface of the matrix : $a$, papillary punctures.

- 4. Spicula of C.celata much enlarged.

- 5. C. spinosa as seen through the transparent matrix, magnified two times.

- 6. A portion of the surface of the matrix exhibiting the papillary punctures :-natural size.

- 7. Spicula of $C$. spinosa much enlarged.

- 8. Triradiate spicula from the surface of Thoosa bulbosa?

\title{
Plate Xiv.
}

Fig. 1. Chambers of C. gorgonioides exposed by the removal of the surface of the matrix, a little enlarged : $a$, papillary punctures.

- 2. C. Fryeri as seen through the transparent matrix; one half enlarged.

- 3. Surface of the matrix of the same, exhibiting the papillary punctures.

- 4. A series exhibiting the development of $C$. Fryeri considerably enlarged : $a$, represents the first stage; $b, c, d, e, f$, the succeeding stages.

- 5. Spicula of $C$. Northumbrica much enlarged.

$\begin{array}{llll}\text { - 6. } & \text { Ditto } & \text { C. gorgonioides } & \text { ditto. } \\ \text { - 7. } & \text { Ditto } & \text { C. gracilis } & \text { ditto. } \\ \text { - 8. } & \text { Ditto } & \text { C. Howsei } & \text { ditto. } \\ \text { - 9. } & \text { Ditto } & \text { C. Fryeri } & \text { ditto. } \\ \text { - 10. } & \text { Ditto } & \text { C. Canadensis } & \text { ditto. }\end{array}$

Plate XV.

Fig. 1. Chambers of $C$. corallinoides exposed by the removal of the surface of the matrix : $a$, papillary punctures.

- 2. Spicula of $C$. corallinoides much enlarged.

$\begin{array}{llll}\text { - 3. } & \text { Ditto } & \text { C. radiata } & \text { ditto. } \\ \text { - 4. } & \text { Ditto } & \text { C. dendritica } & \text { ditto. } \\ -5 . & \text { Ditto } & \text { C. insidiosa } & \text { ditto. } \\ - \text { 6. } & \text { Ditto } & \text { C. quadrata } & \text { ditto. } \\ - \text { 7. } & \text { Ditto } & \text { C. labyrinthica } & \text { ditto. } \\ - \text { 8. } & \text { Ditto } & \text { C. cervina } & \text { ditto. } \\ \text { - 9. } & \text { Ditto } & \text { C. Alderi } & \text { ditto. } \\ \text { - 10. } & \text { Ditto } & \text { C. nodosa } & \text { ditto. } \\ -11 . & \text { Ditto } & \text { C. muscoides } & \text { ditto. } \\ \text { - 12. } & \text { Ditto } & \text { C. vastifica } & \text { ditto. } \\ -13 . & \text { Ditto } & \text { C. angulata } & \text { ditto. }\end{array}$

XXXVII.-On the Mode of Growth in Calothrix and allied Genera. Вy Јонм Ralfs, M.R.C.S., Penzance*.

IN my former communication I remarked that in Oscillatoria the division of the filament is accompanied by that of its sheath, whilst in Microcoleus the sheath is so inflated as not to interfere with the process of division. I shall now endeavour to prove that the appositional branches in Calothrix and other genera are the results of modifications of that mode of division which we see in Oscillatoria and Microcoleus.

* Read before the Botanical Society of Edinburgh, 8th March, 1849. 
In Scytonema, Calothrix, Arthronema, \&c. the sheath is somewhat cartilaginous and closely surrounds the contained filament. As its texture is comparatively firm, it admits only a slight degree of dilatation : it neither separates as in Oscillatoria, nor allows the bundling of the filaments as in Microcoleus.

In all these genera the structure of the filament, irrespective of the sheath, is alike, and consists of a single, longitudinal series of disciform cells which are often confluent or have indistinct dissepiments.

If a specimen of Calothrix or Canocoleus be examined we may frequently observe, especially near the extremities of the branches, short separated portions of filaments in every respect similar to those which sometimes occur in Oscillatoria. At first such a portion is separated from the original filament by a short interval; but as there is no division of the sheath and both portions continue to elongate, they are soon in contact again. In the act of passing each other the extremities sometimes become attenuated. In this state the filament looks as if it had divided obliquely, and the upper portion becoming impacted between the filament and the sheath presents the appearance of a branch. From this explanation it will be evident that the branches in these genera are produced, not by an adhesion of other filaments, but by a dislocation of the filament itself.

Both portions continue to elongate upwards, and branches are thus repeatedly formed by dislocation. The upper portions or branches, however, always retain their original advantage and extend beyond the trunk. This fact seems to me a strong proof of the correctness of the view I have given, for it could scarcely be constant if the branches originated in any other manner.

The frond or sheath is itself truly branched or divided in the ordinary way. Sometimes, as in Calothrix, it is forked as soon as the upper portion becomes impacted, and the plant presents no peculiarity to the eye in its mode of branching except that the branches at the base are not united to the trunk.

In Canocoleus the branching of the sheath does not occur at the same spot as the dislocation of the filament. Upon this circumstance depends the peculiar character of the genus, for after the dislocation the inferior portion as it elongates necessarily pushes itself up by the side of the superior one. Sometimes the filaments are again branched by dislocation before the sheath divides, and thus from two to four (or even more) filaments pass up side by side within a common sheath. Where the sheath forks the filaments are in general equally distributed between its branches.

From what I have stated it will be seen that in Calothrix and Canocoleus the dislocated ends pass each other without any 
alteration of their direction. This is not the case in Scytonema myochrous, which acquires a very different habit owing to the variation in the direction of the dislocated extremities. In that plant the new ends are curved towards the same side of the sheath; they do not pass each other, but issue from the side together and at right angles to its axis. As both portions encounter equal resistance they elongate equally, and consequently the branches are said to be in pairs. Sometimes the dislocation does not take place until after a loop has been formed by a lateral protrusion. Occasionally also the dislocation occurs without any curvature of the newly formed ends, which then pass each other as they do in Calothrix; but this rarely happens except in the case of lower or basal dislocations. The presence in the same specimen of both modes of branching proves that they depend on modifications of the same law, notwithstanding their very different appearance.

Calothrix mirabilis presents another variation in the direction of the dislocated ends. At first sight the mode of branching appears similar to that of Scytonema myochrous, and different only in having more frequent divisions; but closer examination detects an essential difference. The filament indeed separates as in Calothrix and the ends pass each other; but instead of remaining within the same sheath, they immediately pass out obliquely in opposite directions; consequently as both portions are free and continue to elongate, they seem merely to anastomose by cohesion at the convexities of their sheaths. As this plant divides at short intervals, it has the appearance of intricate network.

In Rivularia also the branches are the result of dislocation, but in that genus a globule is formed at the base of the branch at the time of dislocation.

A similar globule is present in the lower branches of some species of Calothrix and Canocoleus; in these however it is usually developed only after the impaction of the branch, but sometimes during the division of the filament. If the lower portion of the filament elongates and passes the vesicle, its appearance does not differ from one formed after dislocation. If the lower portion ceases to grow at the time of division, the plant is like a simple filament here and there interrupted by a vesicle or sporangium.

In this group, however, the branching of the filament is not invariably accompanied by dislocation: in Stigonema I believe it never occurs, and even in Scytonema I have seen some species allied to myochrous in which the branches were apparently produced in the usual manner by lateral protrusion without interruption of continuity. 


\section{$2 \mathrm{BHL}$ Biodiversity Heritage Library}

Ralfs, John. 1849. "XXXVII.-On the mode of growth in Calothrix and allied genera." The Annals and magazine of natural history; zoology, botany, and geology 3, 348-350. https://doi.org/10.1080/03745485909494774.

View This Item Online: https://www.biodiversitylibrary.org/item/71826

DOI: https://doi.org/10.1080/03745485909494774

Permalink: https://www.biodiversitylibrary.org/partpdf/60292

\section{Holding Institution}

University of Toronto - Gerstein Science Information Centre

\section{Sponsored by}

University of Toronto

\section{Copyright \& Reuse}

Copyright Status: NOT_IN_COPYRIGHT

This document was created from content at the Biodiversity Heritage Library, the world's largest open access digital library for biodiversity literature and archives. Visit BHL at https://www.biodiversitylibrary.org. 